\title{
Determinants of Successful Agri - Futures Contracts in India
}

\author{
Dr. Tarunika Jain Agrawal (Corresponding author) \\ Dept. of Financial Studies, University of Delhi \\ Benito Juarez Marg, New Delhi -110068, India \\ Tel:+91-987-108-7407Ｅ-mail: Tarunika.jain@gmail.com \\ Prof Sanjay Sehgal \\ Dept. of Financial Studies, University of Delhi \\ Benito Juarez Marg, New Delhi -110068, India \\ Tel: +91-989-119-9840Ｅ-mail: sanjayfin15@gmail.com \\ Mr Rahul Agrawal \\ Deputy General Manager, IFCI Ltd.
}

IFCI Limited IFCI Tower, 61 Nehru Place, New Delhi-110 019, India

Received: August 5, 2019 Accepted: Oct. 21, 2019 Published: December 1, 2019

doi:10.5296/ajfa.v11i2.15469 URL: https://doi.org/10.5296/ajfa.v11i2.15469

\begin{abstract}
The study empirically examines the factors which impact the success of the Agri commodity futures contracts. Daily data from July 2012 to July 2017 is used for 22 commodities traded on the three national commodity derivatives exchanges and analyzed in a panel data analysis framework. The results of the study suggest that higher volatility in the spot and futures market, competition in terms of multiple exchange listing, the age of the futures contract, lot size and tick size increase the success potential of the agri futures contract. The international listing, the imposition of Commodity transaction tax, a higher number of levels in the value chain and greater geographical coverage in the spot market reduces the liquidity for the contract. Thus, the study identifies important market characteristics and elements of contract design that have implications for the success of agri commodities futures contract in India.
\end{abstract}


Keywords: Agriculture, Futures market, Panel Data Analysis, successful factors, Commodity transaction tax

JEL Classification: G10, G13, Q02, Q18 


\section{Introduction}

Agriculture sector plays a crucial role in a developing economy like India as the industry contributes almost $16 \%$ of Gross domestic product (GDP) and $49 \%$ of employment (Economic Survey 2017-18). The sector is also pivotal as India ranks second in the agricultural production, accounting for about 7.68\% of total global agricultural output (IBEF Report 2018). India dominates the spices market regarding production, consumption, and export.

Agriculture activity is inherently risky owing to the inelastic demand and supply and overdependence on monsoon. Several problems exist in the market for the agri commodities lack of technology, transportation and warehousing facilities, market infrastructure and weak farm-to-market linkages, leading to high price volatility in the market. The vested interest of the middlemen in the markets, inhibiting the knowledge sharing initiatives aggravates the problem. The distress in the agriculture sector has widespread ramifications - rising inflation, unrest among the farmers, and dissatisfaction in the political and social sections. Inefficient price risk management is considered to be one of the key factors why farmers are not able to get out of the vicious circle of poverty. (UNCTAD, 2019)

The market for agriculture goods can be classified into two segments- Spot and derivatives market. The spot market for the agriculture commodities comprises broadly of the mandis, Agricultural Produce Market Committee (APMC), traders (arhatiyas). As per the data provided by the Economic survey 2014-15, principal regulated markets based on geography (the APMCs) are 2477 and submarket yards governed by these APMC's are 4843. APMC Act requires the first-time auction of agri commodities only through the APMC licensed commission agents. APMC levies some charges for providing and facilitating the trade in the spot market from all the players (the market fee from buyers, licensing fees from the functionaries, and commission fees by the agents) in addition to the Mandi tax and Goods and Service Tax (GST). All of this put together distorts the prices in the spot market and cascades into higher rates of commodities and thus creates inflationary pressures in the economy. In 2016, the electronically traded National agricultural market (E-NAM) was inaugurated with its primary objective to create a more organized, transparent and informationally efficient agri spot market. One of the key legislations relating to agriculture is the Essential Commodities Act, 1955. Under this act, primary agriculture goods like rice, wheat, pulses, oilseeds and commercial crop like Jute and copra are procured by the government at the Minimum support prices (MSP).

In India, the government allowed trading in commodity futures nationwide in 2003 on Multi Commodity Exchange of India (MCX), National Commodity and Derivatives Exchange (NCDEX) and National Multi Commodity Exchange of India (NMCE). Presently, NCDEX dominates agricultural commodities derivative market. (SEBI Annual Report, 2015-16). In 2013, a commodities transaction tax (CTT) of $0.01 \%$ on exchange-traded commodity derivatives was imposed, with the exemption to agri derivatives.

Often market participants, regulators, and academicians debate on the role of the commodity derivative market in the Indian context. There has been a contention that the trading in agri commodities have resulted in an increase in the price volatility and led to inflation (Nath and Lingareddy, 2008, Ahmad and Sehgal, 2015). Internationally it is observed that the commodity 
derivative market plays a beneficial role by helping in better price discovery, risk management and information transmission in the market (Purcell and Koontz, 2003, Du, 2004). Though consent is given by the political sections for active commodity futures markets development. Still, the commodity futures market remains highly unpredictable, owing to frequent bans on futures trading of essential commodities. For instance, Government imposed a phase-wise ban beginning from January 2007 when red gram (tur) and black gram (urad) were initially banned, followed by a ban on wheat and rice in February 2007 and on chickpeas (channa), soybean oil, potato, and rubber in May 2008. Forward Markets Commission suspended futures trading in guar seed, pepper, and potato in 2012, 2013, and 2014 respectively. Such a policy was justified by citing futures trading as a source of inflationary pressure on spot prices. In 2015, the Forward Contracts Regulation Act (FCRA) was repealed, and Forward market commission (FMC) was merged with the Securities and Exchange Board of India (SEBI). SEBI classifies agri commodities into various categories, as mentioned in its notification of September 27, 2016, which is followed by the exchanges too. However, for CTT imposition, the segmentation is done differently into two categories - primary and processed agri commodities. Though the agri commodities have been kept outside the purview of CTT, the imposition on agro-processed commodities has created an anomaly. Several studies (Sahoo and Kumar (2008), Sehgal \& Ahmad (2013), Ray and Malik (2014), Kumar et al. (2017), Sehgal and Agrawal (2019)) have confirmed a negative impact of CTT on the liquidity in the commodity market.

It is well established that developing and introducing new derivative contracts is a costly and time-consuming process (Pennings and Leuthold, 2001). Given this important consideration, in January 2017, SEBI, in its effort to ascertain the suitability of commodities for derivatives trading, laid down criteria for identifying such commodities/ products. It defines five broad parameters, namely Commodity fundamentals, Ease of doing business, Trade factors, Risk management and Benchmark potential. Weights and commodity specific subscores are to be assigned by the exchanges and submitted to SEBI when seeking permission to trade. Higher the score better are the prospects of a commodity in futures trade.

However, this is not the first time that an attempt has been made to identify commodities where trading in futures contracts can be more appropriate. In the Indian context, several committees (Dantwala Committee (1956 and 1967), Khusro Committee (1980), Kabra Committee (1994), Habibullah Committee (2003) and Abhijit Sen Committee (2008)) have studied the commodity derivative market and made a comment on whether it fulfils its objective of enhancing price discovery and risk hedging for the participants or not. These studies also observed its impact on the prices and made recommendations to strengthen the regulatory framework, improve related infrastructure and emphasized on the spot and futures market integration. Notably, Khusro Committee (1980) and Kabra Committee (1994) deliberate on characteristics which make derivative trading in the futures for commodity successful. These reports highlighted those commodities which are homogenous, non-perishable, likely to be standardized and have an abundant and uncertain supply and demand to be more suitable for the futures trading. Interestingly, in the absence of empirical analysis, the recommended list of commodities by different studies was in contradiction with each other as in the case of rice, cotton, spices, etc.

As a cumulative effect of the above-mentioned developments in the Indian Agri commodity 
market - frequent suspensions in futures trading, steep special and additional margin requirement, and the imposition of CTT have hurt the market sentiment and hampered the liquidity in the market. It has added distress to the agricultural sector, which suffers from several weaknesses.

Improvement in the agriculture sector can take place only when the institutions in both spot and derivative markets are strengthened (Thomas, 2003). Presence of favourable market sentiment and investor confidence is essential for the agri commodity derivative market to perform its functions of price discovery and risk management effectively and efficiently. The motivation of the present study lies in the substantial economic costs associated with the failure of the futures contract. Not only launching new contracts is an expensive exercise but it also damages the market institutional infrastructure and investors' sentiment. A limited number of the contracts puts the agri commodity derivative market in the vicious circle of low liquidity, which questions the viability and growth prospects of the exchanges and results in dwindling tax revenue collection of the government (Sahoo and Kumar, 2008; Sehgal and Agrawal 2019). The inability of the derivatives market to function efficiently results in negligible innovation and thus there is a constant debate regarding its relevance in the political sections, which leads to frequent interventions and adverse public policy towards the agri derivatives market.

In this context, it is pertinent to empirically identify and examine the factors which have a substantial impact on the success of the agri commodity futures contracts. Furthermore, it would be beneficial to pay attention to elements which are significant to strengthen them to make the contract trading successful. Such analysis provides a strong foundation based on which financial regulator can revisit and reassess the criteria adopted for evaluating the suitability of commodities for derivative trading. As discussed in the next section, literature examining the determinants of success for the Indian agri commodities is virtually absent. Given the importance attached to the agricultural sector in the Indian economy, there is an urgent need for revisiting the agri commodity market for taking necessary policy measures. Specifically, the study aims to identify essential characteristics which distinguish between successful and relatively less successful trading contracts in Indian agri futures market. The proposed criterion is based on an empirical analysis which can guide the policymakers, regulators, exchanges and market participants for the choice of agri commodities which should be permitted and encouraged in the commodity derivative market and which ones to be withdrawn and suspended.

The findings of the study suggest that increased volatility in the spot market increases the likelihood of success for an agri futures contract. Furthermore, increased futures price volatility and increased competition among the exchanges regarding multiple contracts with the same underlying commodity has a positive influence on the trading volume of the futures contract, increasing its success potential. On the other hand, contracts on the underlying commodities which are traded globally on different exchanges are less likely to succeed in the Indian market as there are multiple reference points providing efficient price discovery mechanism thus reducing the liquidity for the contract. The imposition of CTT has a negative impact on contract success. The levels in the value chain and the number of mandis for a commodity exhibit a negative relation with the futures trading volume. The findings highlight that as the age of the 
contract increases, the contract is more successful. Furthermore, tick size, a contract design specification is positively related to contract success. In light of the results of the study, SEBI could re-examine its criteria for incorporating additional factors and reduce the weight of some in its standards.

The paper is organized as follows. The second section presents the literature review. In section 3 , the data and variable construction are discussed. Section 4 presents the methodology and empirical results. The last section contains the conclusion and policy suggestions for agri market development.

\section{Literature review}

In the literature, two main aspects have been studied when analyzing the determinants of successful contracts - definition of success and factors contributing to contract success. The prior work reviewed encompasses studies offering explanations for why a few traded contracts achieve the liquidity, requisite for success and some experience low liquidity and failure in general and some studies specifically in the context of agricultural commodities (Bialkowski and Jakubowski, 2012; Till, 2014; Webb, 2015; Garcia et al., 2015). It helps us to identify broad characteristics essential to the success of the contract and specifically examine them in the context of agricultural commodities in India. Not all future contracts that are launched succeed i.e. they are characterized by low volume reflecting less interest from the market participants (Sandor 1973, Silber 1981, Carlton 1984, Black, 1986, Kolb 1991, Thompson and Kunda 2000, Pennings and Leuthold 2001, Brorsen \& Fofana 2001).

Previous studies suggest alternative measures of success. Some studies measure success based on the length of the time that the contract has been trading for (Silber, 1981) and others based on the levels of trading volumes associated with the contract. Sandor (1973) takes the annual trading volume of 1000 contracts as a cut off for identifying successful contract. Some studies also examine daily trading volumes like Dew (1981) and Carlton (1984) - 10,000 contracts and 1,000 contracts on a daily basis respectively. Holder et al. (1999) took 10000 contracts as the monthly trading volume for identifying a successful contract. Gorham and Kundu (2012) categorize contracts into highly successful, successful, moderately successful and failure by the 5th year trading volume. A broad consensus is established from the previous studies in favour of trading volume over different periods as a measure of success.

Prior literature (For examples; see Baer and Saxon (1949), Gray (1966), Powers (1967), Black (1986), Brown et al. (1991), Tashjian (1995), Harris (1998), Karagozoglu and Martell (1999), Longin (1999), Brorsen and Fofana (2001), Pennings and Garcia (2001), Pennings and Leuthold (2001), Meulenberg and Pennings (2002), Bollen et al. (2003) and Pennings and Egelkraut (2003)) also highlights that commodities differ in characteristics which influence their potential to be successful in the futures trading. Few of the earlier studies, Gray (1966) summaries the following factors resulting in future contracts to fail. 1. Legal aspect - many government policy interventions; 2 . Loss of economic basis - the need for hedging; 3 . Contract neutrality - towards favoring either the buyer or seller; 4. Disposition of large firms to use market power to boycott the futures market; 5. Futures markets failing to attract speculators, agents who provide liquidity; and 6. Different expiration months and seasonality of production. 
Hyeronymus (1977) reinforce these considerations in his study. Black (1986) focuses on commodity-specific characteristics like homogeneity, storability, spot market size, considerable variations in prices for identifying successful contracts (contracts with high trading interest). Corkish et al. (1997) conclude that the volume and volatility of the spot market are essential conditions for a future contract to be successful. Cornell (1981) indicates the variability in the spot market prices to be the most significant factor. Thompson et al. (1996) attribute the demise of the corn syrup future to a highly concentrated market and poor contract specifications, less homogenous product; small sized spot market and the inability of the contract to attract sufficient participants in the futures market. Williams et al. (1998) make an interesting observation about the positive influence of futures trading on the China Zhengzhou commodity exchange on the spot market practices, like the adoption of better-quality standards. Sanders and Pennings (1999) suggest the role of poor contract design and high transactions cost involved in the failure of Minneapolis Grain Exchange's white shrimp futures contracts. They also underline the role played by the presence of an efficient alternative risk hedging mechanism.

Brorsen and Fofana (2001) assessed the factors specifically for the agricultural commodities and highlighted the significant role played by the spot/ cash market characteristics like the number of levels in the value chain, buyer concentration and an active cash market in the contract success. Bollman et al. (2003) observe that diammonium phosphate futures contract at Chicago Board of Trade (CBOT) failed because of a weak association between the spot and futures prices, making the futures contract to be an inefficient tool for price risk management. Siqueira, da Silva, and Aguiar (2008) recommend the introduction of milk futures contracts in Brazil by analyzing various aspects specific to commodity and markets. They highlight the role of high volatility and competition in the spot market, the absence of traditional risk management mechanism and no cross-hedge possibility in their explanation. Tavares (2008) found high transaction costs, poor knowledge of futures among farmers and highly concentrated market, the presence of forwards contracts, which was adequately fulfilling the need for hedging, to be the factors causing the Intercontinental Exchange (ICE) futures contract on orange juice to fail. Hosseini-Yekani et al. (2009) find saffron, pistachio, and rice to be fit for the launch of an agri futures contract by analyzing factors including basis risk in the futures trading, size, and volatility of the cash market, homogeneity and the level of exports to total supply. Hung et al. (2011) examined ten contracts from six exchanges in East Asia from January 2001 to February 2007 and concluded spot market volatility, smaller contract size and existence of cross-hedging product to have a beneficial impact on the contract's successfulness. Quintino and David (2013) examine the relationship between the hydrous ethanol spot and futures to assess its feasibility on the São Paulo stock exchange. They study factors like the cross-hedging possibilities, competition, spot market volatility and correlations between the possible substitutes for the period May 2010 to April 2012. The findings point out the role of highly concentrated nature of the sector in impairing contract liquidity, in spite of all others requirements for being successful were met. Till (2014) illustrates three essential elements that determine success by discussing various case studies. It shows that a contract can be successful only if there is a need felt for hedging commercially, the market can attract speculators for trading and the favourable role of public policy. Webb (2015) underlines the significant 
influence of cash market volatility, fulfilling hedging requirement, participation by hedgers and speculators, the presence of related contracts, liquidity, the timing of the launch, trading costs and contract specifications on the contact success. Roche (2016) examines various factors influencing the success of the Red chilli contract of Pakistan Mercantile Exchange launched on September 2015 and highlight the role of price volatility and liquidity in the market for the continued success of the contract. Bekkerman and Tejeda (2017) attempt to find out the reason for the futures contract success by analyzing the data for 21 agricultural products listed on the North American futures exchange throughout January 2007 and September 2012. The study concludes that the activeness of the spot and cross hedge futures market, variability in the spot market, the degree of homogeneity, level of vertical integration and market power concentration significantly explain futures market's success. Sittisawad \& Sukcharoensin (2018) conclude size, volatility and liquidity in the cash segment and tick size, contract size and option-type in the futures market segment to contribute to financial derivative's success in the context of six select Asian exchanges using a panel regression method. Białkowski \& Koeman (2018) underpin the presence of an efficient spot market for a contract to be successful when analyzing dairy futures contract for the period of 2012 to 2015 in the US and New Zealand market. These studies have been conducted for the international commodity markets.

Nevertheless, the factors influencing the success potential of the commodities in the derivatives market needs to be explored further, as suggested by Bhardwaj, Gorton, and Rouwenhorst (2015). In the Indian context, prior empirical work mainly focuses on the destabilization effects and information linkages between the spot and futures market. (Thomas and Karande (2001), Sahi \& Raizada (2006), Iyer and Pillai (2010), Shihabudheen and Padhi (2010), Kumar and Shollapur (2015), Seth \& Sidhu (2018), Gupta et al. (2018)).

In a recent study, Gulati et al. (2017) propose criteria based on Principal Component Analysis for ten commodities over the period $2010-2013$ to identify factors influencing the success of the future contract in the Indian context. The study points out those commodities which are not sensitive from the perspective of food security, have price variation, and a large share in the global trade and huge surplus are more suitable for future trading as they are less prone to government interventions. However, this study presents the necessary but not sufficient conditions for the contract to be successful. For instance, the success of the futures contract may also depend on market characteristics and contract specification as shown by prior international work.

The present study is an endeavour to address this gap by identifying essential characteristics which distinguish between successful and non-successful trading contracts and recommend criteria based on empirical analysis for the choice of agri commodities which should be permitted and encouraged in the commodity derivative market.

\section{Data and variable description}

Because of data availability constraints, we use daily data for about five years (July 2012 to July 2017) for 22 commodities traded on the three national commodity derivatives exchange MCX, NCDEX, and NMCE. In case the commodity is traded at multiple exchanges, contract with the higher trading volume has been selected, in particular, crude palm oil. Futures contract 
on commodities like Black pepper, castor seed and RBD Palmolien on MCX, Chana, $29 \mathrm{~mm}$ cotton, castor seed, degummed soy oil, Mustard seed oil cake, and pepper on NCDEX were introduced in the year 2017 only and thus were not included in the analysis. Data for Guar seed, Shankar Kapas on NCDEX, Copra and Sacking on NMCE was not available and therefore excluded. The sample commodities represent the significant categories of the Indian agricultural market - Cereals and Pulses, oil and Oil Seeds, Spices and others. However, the data can be said to suffer from survival bias. (Haugen and Baker (1996).

Following prior work (See Black, 1986; Brorsen and Fofana, 2001 and Hung et al., 2011), we use the natural log of trading volume (of near month future contract) as a measure of success. Based on the literature review, we identify and discuss the following characteristics in detail under two broad categories - Spot market and futures market characteristics. The spot market characteristics help determine the viability, and the future market factors offer to augment understanding of the elements for the sustained success of the futures contract.

\subsection{Spot Market Characteristics}

3.1.1 Spot market size (CMS) - - The size of the spot market indicates the trading interest in terms of the possible number of participants for the derivatives market. Ideally, greater the spot market size, higher the success of the futures contract. The physical market size is the natural $\log$ of annual production (in tons). Exhibit A summarizes the data sources for different commodities, taken from multiple sources.

Exhibit A. The data sources for different commodities

\begin{tabular}{|c|c|}
\hline Commodity & Source \\
\hline $\begin{array}{l}\text { Wheat, Barley, Cottonseed oilcake, Crude palm oil, } \\
\text { Refined soy oil }\end{array}$ & $\begin{array}{l}\text { United States Department of } \\
\text { Agriculture (USDA) Foreign } \\
\text { Agricultural Service }\end{array}$ \\
\hline Cotton, Rapeseed, Soybean, V 797 Kapas & Reserve Bank of India (RBI) \\
\hline Maize (Kharif, rabi), Castor Seed & $\begin{array}{l}\text { Directorate of Economics and } \\
\text { Statistics, Department of } \\
\text { Agriculture, Govt. of India }\end{array}$ \\
\hline Mentha Oil & $\begin{array}{l}\text { Council of Scientific and } \\
\text { Industrial Research - Central } \\
\text { Institute of Medicinal and } \\
\text { Aromatic Plants (CSIR-CIMAP) }\end{array}$ \\
\hline Sugar & $\begin{array}{l}\text { Agricoop Sugar Report 2017, } \\
\text { Department of Agriculture } \\
\text { Cooperation \& Farmers Welfare, } \\
\text { Govt. of India }\end{array}$ \\
\hline Isabgul seed & $\begin{array}{l}\text { Psyllium seed report } 2016 \\
\text { (https://www.premcemgums.com/psy } \\
\underline{\text { llium-seed-2016-crop-report/) }}\end{array}$ \\
\hline
\end{tabular}

3.1.2 Spot market activeness (SMA) - The primary data required for calculating spot market activeness is spot prices. The data is retrieved from the respective exchanges where the contract 
on the commodity is listed and the gaps were filled with the help of Agriwatch. Following Bekkerman and Tejeda (2017) we calculate spot market activeness. The first difference of the weekly prices is used (as daily price data commonly doesn't exhibit substantial change) and a 26-period lagged value is generated. Over the rolling window of 26 weeks, we record the mean number of times when there was no difference in the price. A 95\% confidence interval is calculated, and the mean values are tested for their significance. The market is categorized as a highly active market if the mean number of times the weekly price levels are significantly different from zero. A dummy variable takes a value 1 for a highly active market and vice versa.

3.1.3 Spot market Volatility (SPV) - We calculate spot market volatility in terms of the annualized standard deviation of daily spot price log returns. It is a prerequisite for the success of the futures contract as higher the price volatility; more significant is the need for hedging it and thus more participation in the future market.

3.1.4 Level of vertical integration (VI) - This variable captures the length of the value chain. Previous Studies (See Brorsen and Fofana, 2001; Bekkerman and Tejeda, 2017) suggest that more extensive the value chain is, higher the number of participants involved in derivatives trading of such commodity. More points of the transaction in the value chain because of low vertical integration results in higher likelihood of futures markets. We take the information about the value chain from the product note for particular commodities on the exchange on which it is traded.

3.1.5 Geographical coverage (GC) - According to SEBI, higher geographic coverage would attract a higher number of participants to the derivatives. On the contrary, having access to a higher number of mandis increases the bargaining power of farmer vis-à-vis intermediaries helping them get a better price for their produce. To empirically verify its significance in the Indian context a dummy variable is included, which takes a value of 1 for high geographical coverage and 0 otherwise to avoid the noise in data, due to large variation in the number of mandis ranging from 1 mandi to about 400 mandis for different commodities. To assess the degree of geographical coverage, we record the average number of mandis over the five years and calculate the median number of mandis across all commodities. If the number of mandis for a commodity is lower than the median, it is categorized as a low geographical coverage and vice versa.

3.1.6 The degree of homogeneity (HOMO) - The success of the futures contract is inhibited by a considerable quality difference among the commodities, leading to the market being segmented and reduced resultant participation in the futures market. This variable is measured by the number of variants in which the commodity is traded in the spot market. We obtain the data from the AGMARK website.

3.1.7 Covered in the essential commodities act (EC) - It is theorized that commodities which have too many restrictions are less favourable for derivatives markets and additionally if the traditional risk mitigation tools work efficiently then the futures contract is likely to fail (Siqueira et al.2008). In the Indian context, the government regulates essential commodities through various measures like price control or buying the commodities directly from farmers at a fixed price, reducing price fluctuations and hampering the futures contract success potential. 
We create a dummy variable which takes a value of 1 if the commodity is covered under the Essential Commodities Act and 0 otherwise. The data for the same is sourced from DES, Ministry of Agri.

\subsection{Future Market Characteristics}

We obtain the data related to future prices, volume and open interest of near month future contract from Bloomberg.

3.2.1 Hedging effectiveness (HE) - Following Corkish et al. (1997), we estimate the hedging effectiveness by the coefficient of determination of the regression equation: $R S_{t}=a+b * R F_{t}+$ $e_{t}$ where the spot (futures) return $R S_{t}\left(R F_{t}\right)$ are defined as logarithmic price changes. The more successful contracts should provide more effective risk reduction

3.2.2 Futures price volatility (FPV) - Volatility is the annualized standard deviation of daily futures price returns (assuming 250 trading days). Higher volatility in the futures market leads to higher participation of speculators, and thus a positive impact is expected.

3.2.3 Commodity Transaction Tax (CTT) - We use 0, 1 dummy to study the effect of CTT imposition, where it is equal to 1 if CTT is imposed and 0 otherwise. CTT imposition increases the cost of trading of contracts resulting in lesser chances of it becoming successful (Webb, 2015, Sehgal \& Agrawal, 2019).

3.2.4 Competition (COMP) - We create a dummy variable taking a value of 1 when a similar contract exists on another Indian exchange (MCX, NCDEX, and NMCE) and 0 otherwise. Competing contracts may divert trading from the existing market (Black (1986) and Brorsen and Fofana (2001). Alternatively, some studies point to that competition may have a positive impact too through more revenue generation (Tashjian and Weissman (1995); Corkish et al. (1997); Hung et al. 2011)) and spread trading (Webb, 2015)

3.2.5 Internationally listed (INT) - Theoretically, Corkish et al. (1997); Siqueira, da Silva, and Aguiar (2008); Hung et al. (2011), the international listing (listed on an exchange outside of India) could be a conducive factor for derivatives trading by creating multiple reference points, incorporating the influence of global factors. Conversely, it is also postulated that in the presence of a cross hedge, a new derivatives contract would find it difficult to succeed in the face of competition. If the commodity is internationally listed, then there is increased competition from other exchanges. We collect information about the contract listing from the websites of major international exchanges for agricultural goods, namely ICE, CBOT, New York Mercantile Exchange (NYMEX), Tokyo Commodity Exchange (TOCOM), Chicago Mercantile Exchange (CME), and Bursa Malaysia. We define a dummy variable equal to 1 when a commodity is traded on international exchange and 0 otherwise.

3.2.6 Contract specifications - One of the critical aspects emphasized for the success of the contract is the contract design (See Gray 1966, Pennings and Meulenberg, 1997, Black 1986, Pennings and Leuthold, 2001). Contract design is relevant as it should appeal to both hedgers and speculators. The absence of speculators, as suppliers of liquidity, will have an adverse impact on market development. Tick size, lot size and the age of the contract have an 
undeniable role in determining the contract success. The information related to contract specifications like launch date, lot size and tick size is obtained from the respective exchanges in their product notes for the commodities.

- Age of the contract - Silber (1981) and Kolb (1991) have provided evidence of the same indicating only about one-third of the new contracts sustain on the exchange. Thus, old contracts are expected to be more successful. We calculate the age of each contract by the number of days it has been traded since its launch date.

- Size of the contract - The literature suggests the optimal contract size as one which can attract small participants as well as minimize transaction costs (See Hull, 2000; Purcell and Koontz, 2003). Smaller contracts draw interest from a higher number of players because the related risks are relatively lesser. On the other hand, a small contract suffers from the issue of greater administrative expense, which can be offset if there are higher volumes in the derivatives market. (Siqueira, da Silva, and Aguiar (2008); Hung et al. (2011), Webb 2015). We measure the contract size by estimating the amount of money required to trade one lot of the commodity contract (Future price * lot size).

- $\quad$ Tick size - Tick size is the minimum price movement in the contract. Theory suggests that a decrease in the tick size results in an increase in the market liquidity (see Brown et al. (1991), Chordia and Subrahmanyam (1995), Ahn et al. (1996), Frino (1997) and Kurov and Zabotina (2005), improvement in the price discovery and informational efficiency (See Kurov 2008). Some studies have also concluded that a decrease in the tick size results in improved liquidity for highly liquid stocks and the opposite holds for the less liquid stocks (Harris (1994), Niemeyer \& Sandås (1994); Ahn et al. (1996); Grossman et al. (1997), Goldstein \& Kavajecz (2000). In the present study, we measure tick size in rupee terms for all contracts (lot size* tick size)

Table 1 presents a list of commodities and a summary of the factors where dummy variables are used in the study

Table 1. List of commodities and summary of research variables used

\begin{tabular}{|l|l|l|l|l|l|l|l|l|l|l|l|}
\hline $\begin{array}{l}\text { S. } \\
\text { NO. }\end{array}$ & $\begin{array}{c}\text { Commoditi } \\
\text { es }\end{array}$ & $\begin{array}{c}\text { Categor } \\
\mathrm{y}\end{array}$ & $\begin{array}{c}\text { Exchan } \\
\text { ge from } \\
\text { which } \\
\text { data is } \\
\text { taken }\end{array}$ & $\begin{array}{c}\text { Launch } \\
\text { date }\end{array}$ & Lot size & $\begin{array}{c}\text { Tick } \\
\text { Size }\end{array}$ & $\begin{array}{c}\text { Presenc } \\
\text { e of } \\
\text { cross } \\
\text { hedge }\end{array}$ & $\begin{array}{c}\text { Listing } \\
\text { on an } \\
\text { internati } \\
\text { onal } \\
\text { exchang } \\
\text { en }\end{array}$ & $\begin{array}{c}\text { CTT } \\
\text { Impositi }\end{array}$ & $\begin{array}{c}\text { Industry } \\
\text { Vertical } \\
\text { Integrat } \\
\text { ion }\end{array}$ & $\begin{array}{c}\text { MSP } \\
\text { applica } \\
\text { ble }\end{array}$ \\
\hline 1 & Barley & $\begin{array}{l}\text { Cereals } \\
\text { and } \\
\text { Pulses }\end{array}$ & $\begin{array}{l}\text { NCDE } \\
\mathrm{X}\end{array}$ & $\begin{array}{l}29 \text { Nov } \\
2006\end{array}$ & $10 \mathrm{mt}$ & 0.5 & No & Yes & No & Low & Yes \\
\hline 2 & Cardamom & Spices & MCX & $\begin{array}{l}11 \text { Feb } \\
2006\end{array}$ & quintal & 0.1 & Yes & No & No & High & No \\
\hline 3 & $\begin{array}{l}\text { Castor } \\
\text { Seed }\end{array}$ & $\begin{array}{l}\text { Oil and } \\
\text { Oilseed }\end{array}$ & NMCE & $\begin{array}{l}02 \mathrm{May} \\
2012\end{array}$ & $10 \mathrm{mt}$ & 1 & No & No & No & Low & No \\
\hline
\end{tabular}




\begin{tabular}{|c|c|c|c|c|c|c|c|c|c|c|c|}
\hline & & $\mathrm{s}$ & & & & & & & & & \\
\hline 4 & Cotton & Fibres & MCX & $\begin{array}{l}01 \text { Oct } \\
2011\end{array}$ & 25 bales & 10 & No & Yes & No & High & Yes \\
\hline 5 & $\begin{array}{l}\text { Cottonseed } \\
\text { Oil Cake }\end{array}$ & $\begin{array}{l}\text { Oil and } \\
\text { Oilseed } \\
\mathrm{s}\end{array}$ & $\begin{array}{l}\text { NCDE } \\
\mathrm{X}\end{array}$ & $\begin{array}{l}22 \text { July } \\
2009\end{array}$ & $10 \mathrm{mt}$ & 1 & No & No & No & Low & No \\
\hline 6 & $\begin{array}{l}\text { Crude } \\
\text { Palm Oil }\end{array}$ & $\begin{array}{l}\text { Oil and } \\
\text { Oilseed } \\
\mathrm{s}\end{array}$ & MCX & $\begin{array}{l}04 \text { Sep } \\
2004\end{array}$ & $10 \mathrm{mt}$ & 0.1 & Yes & Yes & Yes & Low & No \\
\hline 7 & Coriander & Spices & $\begin{array}{l}\text { NCDE } \\
\mathrm{X}\end{array}$ & $\begin{array}{l}11 \text { Aug } \\
2008\end{array}$ & $10 \mathrm{mt}$ & 1 & Yes & No & No & High & No \\
\hline 8 & Guar Gum & Others & $\begin{array}{l}\text { NCDE } \\
\mathrm{X}\end{array}$ & $\begin{array}{l}27 \text { July } \\
2004\end{array}$ & $5 \mathrm{mt}$ & 1 & No & No & Yes & Low & No \\
\hline 9 & $\begin{array}{l}\text { Isabgulsee } \\
\text { d }\end{array}$ & Others & NMCE & $\begin{array}{l}05 \text { Mar } \\
2006\end{array}$ & $\begin{array}{l}10.125 \\
\text { MT } \\
(135 \\
\text { bags of } \\
75 \mathrm{Kgs})\end{array}$ & 0.1 & No & No & No & Low & No \\
\hline 10 & Jeera & Spices & $\begin{array}{l}\text { NCDE } \\
\mathrm{X}\end{array}$ & $\begin{array}{l}03 \text { Feb } \\
2005\end{array}$ & $3 \mathrm{mt}$ & 5 & No & No & No & High & No \\
\hline 11 & $\begin{array}{l}\text { Maize } \\
\text { (Kharif) }\end{array}$ & $\begin{array}{l}\text { Cereals } \\
\text { and } \\
\text { Pulses }\end{array}$ & $\begin{array}{l}\text { NCDE } \\
\mathrm{X}\end{array}$ & $\begin{array}{l}24 \text { June } \\
2013\end{array}$ & $10 \mathrm{mt}$ & 1 & No & Yes & No & Low & Yes \\
\hline 12 & $\begin{array}{l}\text { Maize } \\
\text { (Rabi) } \\
\text { industrial } \\
\text { grade }\end{array}$ & $\begin{array}{l}\text { Cereals } \\
\text { and } \\
\text { Pulses }\end{array}$ & $\begin{array}{l}\text { NCDE } \\
\mathrm{X}\end{array}$ & $\begin{array}{l}19 \text { May } \\
2010\end{array}$ & $10 \mathrm{mt}$ & 1 & No & Yes & No & Low & Yes \\
\hline 13 & Mentha Oil & Others & MCX & $\begin{array}{l}21 \text { April } \\
2005\end{array}$ & $\begin{array}{l}360 \mathrm{~kg}- \\
2 \text { drums }\end{array}$ & 0.1 & No & No & Yes & High & No \\
\hline 14 & $\begin{array}{l}\text { Rape/Must } \\
\text { ard Seed }\end{array}$ & $\begin{array}{l}\text { Oil and } \\
\text { Oilseed } \\
\mathrm{s}\end{array}$ & $\begin{array}{l}\text { NCDE } \\
\mathrm{X}\end{array}$ & $\begin{array}{l}21 \text { Dec } \\
2004\end{array}$ & $10 \mathrm{mt}$ & 1 & Yes & Yes & No & High & Yes \\
\hline 15 & Raw Jute & Fibres & NMCE & $\begin{array}{l}07 \text { June } \\
2004\end{array}$ & $10 \mathrm{mt}$ & 0.1 & No & No & No & High & Yes \\
\hline 16 & $\begin{array}{l}\text { Refined } \\
\text { Soy Oil }\end{array}$ & $\begin{array}{l}\text { Oil and } \\
\text { Oilseed } \\
\mathrm{s}\end{array}$ & $\begin{array}{l}\text { NCDE } \\
\mathrm{X}\end{array}$ & $\begin{array}{l}04 \text { Dec } \\
2008\end{array}$ & $10 \mathrm{mt}$ & 0.05 & Yes & Yes & Yes & Low & Yes \\
\hline 17 & Rubber & Fibres & NMCE & $\begin{array}{l}15 \text { Mar } \\
2003\end{array}$ & $1 \mathrm{mt}$ & 10 & No & Yes & Yes & High & No \\
\hline 18 & Soybean & $\begin{array}{l}\text { Oil and } \\
\text { Oilseed } \\
\mathrm{s}\end{array}$ & $\begin{array}{l}\text { NCDE } \\
\mathrm{X}\end{array}$ & $\begin{array}{l}15 \text { Jan } \\
2004\end{array}$ & $10 \mathrm{mt}$ & 1 & No & Yes & No & Low & Yes \\
\hline 19 & Sugar M & Others & NCDE & 27 July & $10 \mathrm{mt}$ & 1 & No & Yes & Yes & High & Yes \\
\hline
\end{tabular}




\begin{tabular}{|c|c|c|c|c|c|c|c|c|c|c|c|}
\hline & & & X & 2004 & & & & & & & \\
\hline 20 & Turmeric & Spices & $\begin{array}{l}\text { NCDE } \\
\mathrm{X}\end{array}$ & $\begin{array}{l}27 \text { July } \\
2004\end{array}$ & $5 \mathrm{mt}$ & 2 & No & No & No & High & No \\
\hline 21 & $\begin{array}{l}\text { V-797 } \\
\text { Kapas }\end{array}$ & Fibers & $\begin{array}{l}\text { NCDE } \\
\mathrm{X}\end{array}$ & $\begin{array}{l}07 \text { Aug } \\
2006\end{array}$ & $\begin{array}{l}1 \text { lot } \\
(200 \\
\text { maunds } \\
\text { of } 20 \mathrm{~kg} \\
\text { each) }\end{array}$ & 0.5 & No & No & No & Low & No \\
\hline 22 & Wheat & $\begin{array}{l}\text { Cereals } \\
\text { and } \\
\text { Pulses }\end{array}$ & $\begin{array}{l}\text { NCDE } \\
\mathrm{X}\end{array}$ & $\begin{array}{l}02 \text { July } \\
2004\end{array}$ & $10 \mathrm{mt}$ & 1 & No & Yes & No & Low & Yes \\
\hline
\end{tabular}

\section{Methodology and Results}

In the analysis, we measure returns as the log difference in price for each of the commodities (both in the futures and spot market). As shown in Table 2, the results of the Augmented Dickey-Fuller (ADF) test indicate the return series in both markets to be stationary. 
Table 2. ADF results for the test of stationarity for the return series in the spot and the futures market

\begin{tabular}{|c|c|c|c|c|}
\hline \multirow{2}{*}{$\begin{array}{l}\text { (H0: unit root vs. } H A: \text { no } \\
\text { unit root) } \\
\text { Commodity }\end{array}$} & \multicolumn{2}{|c|}{ Spot market Return } & \multicolumn{2}{|c|}{ Futures market Return } \\
\hline & t-Statistic & Prob.* & t-Statistic & Prob.* \\
\hline Barley & -34.34 & 0.00 & -36.99 & 0.00 \\
\hline Cardamom & -28.88 & 0.00 & -32.52 & 0.00 \\
\hline Castor Seed & -30.33 & 0.00 & -21.37 & 0.00 \\
\hline Cotton & -26.44 & 0.00 & -35.60 & 0.00 \\
\hline Cottonseed Oil Cake & -20.09 & 0.00 & -35.56 & 0.00 \\
\hline Crude Palm Oil & -34.23 & 0.00 & -23.45 & 0.00 \\
\hline Coriander & -34.69 & 0.00 & -36.81 & 0.00 \\
\hline Guar Gum & -33.58 & 0.00 & -28.61 & 0.00 \\
\hline Isabgul seed & -23.73 & 0.00 & -18.73 & 0.00 \\
\hline Jeera & -31.64 & 0.00 & -35.37 & 0.00 \\
\hline Maize (Kharif) & -27.14 & 0.00 & -16.44 & 0.00 \\
\hline Maize (Rabi) & -32.63 & 0.00 & -31.28 & 0.00 \\
\hline Mentha Oil & -37.40 & 0.00 & -36.58 & 0.00 \\
\hline Rape/Mustard Seed & -84.22 & 0.00 & -35.09 & 0.00 \\
\hline Raw Jute & -24.18 & 0.00 & -26.11 & 0.00 \\
\hline Refined Soy Oil & -24.73 & 0.00 & -35.30 & 0.00 \\
\hline Rubber & -24.64 & 0.00 & -14.47 & 0.00 \\
\hline Soybean & -33.91 & 0.00 & -33.73 & 0.00 \\
\hline Sugar M & -34.55 & 0.00 & -24.53 & 0.00 \\
\hline Turmeric & -3.45 & 0.02 & -35.77 & 0.00 \\
\hline V- 797 Kapas & -11.52 & 0.00 & -35.07 & 0.00 \\
\hline Wheat & -34.24 & 0.00 & -39.76 & 0.00 \\
\hline
\end{tabular}

Notes: Number of minimum lags have been chosen according to minimizing of Schwarz Information Criterion (SIC).

Table 3 presents mean values of trading volume in the futures market and spot market capitalization for sample commodities along with the return and volatility for the spot and future market. As shown in Table 3 Column 2, Soybean, followed by refined soy oil and crude palm oil are the top three traded commodities, when looking at the traded volume in the futures market. Cotton records the lowest trading volume in the future market, in spite of the highest spot market capitalization (Column 5). Column 3 indicates that the mean return in the futures market is close to zero for most of the sample commodities, with the highest for Raw Jute and lowest for castor seed. Barley, Jeera, Turmeric, and rubber show positive future market return when at the same time the spot returns are negative. The converse holds for castor seed, Isabgul seed, Maize Kharif, and V 797 Kapas. As shown in Column 6, Isabgul seed shows the highest return in the spot market.

Additionally, Guar gum has the least spot market return and the highest spot market volatility. 
Cotton has the least spot market volatility, as observed in Column 7. Furthermore, in the case of jeera, menthe oil, soybean, turmeric, dhaniya, guar gum, the spot market volatility is higher than the future market volatility. The future market volatility is highest for raw jute and lowest for sugar (see Column 4)

Table 3. Mean values for the research variables for the commodities

\begin{tabular}{|c|c|c|c|c|c|c|}
\hline \multicolumn{2}{|r|}{ Mean values } & \multicolumn{3}{|c|}{ Futures market } & \multicolumn{2}{|c|}{ Spot market } \\
\hline Commodities & $\begin{array}{c}\text { Trading volume (in no. of } \\
\text { lots) }\end{array}$ & $\begin{array}{l}\text { Mean } \\
\text { return }\end{array}$ & $\begin{array}{l}\text { Standard } \\
\text { Deviation }\end{array}$ & $\begin{array}{c}\text { CAP (In } \\
\text { Rs) }\end{array}$ & $\begin{array}{l}\text { Mean } \\
\text { return }\end{array}$ & $\begin{array}{l}\text { Standard } \\
\text { Deviation }\end{array}$ \\
\hline 1 & 2 & 3 & 4 & 5 & 6 & 7 \\
\hline Barley & 2154 & $0.00 \%$ & $1.53 \%$ & 2462.67 & $-0.01 \%$ & $0.87 \%$ \\
\hline Cardamom & 1677 & $-0.02 \%$ & $2.83 \%$ & 17.19 & $-0.03 \%$ & $1.12 \%$ \\
\hline Castor Seed & 3894 & $-0.75 \%$ & $99.16 \%$ & 6656.71 & $0.04 \%$ & $1.42 \%$ \\
\hline Cotton & 1331 & $0.01 \%$ & $1.05 \%$ & 617931.61 & $0.01 \%$ & $0.69 \%$ \\
\hline $\begin{array}{l}\text { Cottonseed Oil } \\
\text { Cake }\end{array}$ & 30671 & $0.01 \%$ & $1.94 \%$ & 7401.18 & $0.02 \%$ & $1.18 \%$ \\
\hline Crude Palm Oil & 40731 & $-0.01 \%$ & $1.10 \%$ & 103.06 & $-0.01 \%$ & $1.12 \%$ \\
\hline Coriander & 11832 & $0.01 \%$ & $2.39 \%$ & 3642.58 & $0.00 \%$ & $2.69 \%$ \\
\hline Guar Gum & 5640 & $-0.14 \%$ & $2.48 \%$ & 14008.20 & $-0.13 \%$ & $4.22 \%$ \\
\hline Isabgulseed & 8778 & $-0.16 \%$ & $107.30 \%$ & 1024.83 & $0.10 \%$ & $0.78 \%$ \\
\hline Jeera & 4605 & $0.02 \%$ & $1.46 \%$ & 6554.39 & $-0.02 \%$ & $1.51 \%$ \\
\hline Maize (Kharif) & 3480 & $-0.04 \%$ & $1.20 \%$ & 23701.33 & $0.01 \%$ & $1.33 \%$ \\
\hline Maize (Rabi) & 3605 & $0.01 \%$ & $1.38 \%$ & 8824.52 & $0.03 \%$ & $1.17 \%$ \\
\hline Mentha Oil & 2835 & $-0.03 \%$ & $1.63 \%$ & 33.12 & $-0.03 \%$ & $1.69 \%$ \\
\hline $\begin{array}{c}\text { Rape/Mustard } \\
\text { Seed }\end{array}$ & 33134 & $-0.01 \%$ & $1.24 \%$ & 30404.96 & $0.00 \%$ & $0.94 \%$ \\
\hline Raw Jute & 3708 & $0.49 \%$ & $109.24 \%$ & 9319.79 & $0.03 \%$ & $0.76 \%$ \\
\hline Refined Soy Oil & 49029 & $-0.01 \%$ & $1.03 \%$ & 10353.44 & $-0.02 \%$ & $0.87 \%$ \\
\hline Rubber & 14096 & $0.21 \%$ & $81.90 \%$ & 170050.24 & $-0.04 \%$ & $0.86 \%$ \\
\hline Soybean & 54367 & $-0.01 \%$ & $1.41 \%$ & 39521.37 & $-0.03 \%$ & $1.85 \%$ \\
\hline Sugar M & 14439 & $-0.02 \%$ & $0.77 \%$ & 77632.12 & $-0.02 \%$ & $1.01 \%$ \\
\hline Turmeric & 12681 & $0.03 \%$ & $2.06 \%$ & 6709.55 & $-0.03 \%$ & $2.16 \%$ \\
\hline V- 797 Kapas & 5394 & $-0.01 \%$ & $1.39 \%$ & 29167.79 & $0.01 \%$ & $0.88 \%$ \\
\hline Wheat & 6927 & $0.02 \%$ & $1.16 \%$ & 152599.12 & $0.03 \%$ & $0.95 \%$ \\
\hline
\end{tabular}

The trading volume is measured in the average annual number of lots traded, Mean return in the futures (spot) market is the average of annual return in the futures (spot) market in percentage; Mean Standard deviation is the annualized measure of volatility in percentage; CAP, Spot market capitalization is measured by the annual spot market volumes (in million 
tonnes) multiplied with the yearly average price in the spot market.

To conclude about the significance of the various determining factor of contract success, we use panel data analysis for the total sample period from 2012 to 2017. Hausman test recommends random effects model.

$$
\begin{aligned}
Y_{i, t}=\alpha_{i}+\beta_{1}(S P V)+\beta_{2}(C M S)+\beta_{3}(S M A)+\beta_{5}(\mathrm{VI})+\beta_{5}(G C)+\beta_{6}(H O M O)+\beta_{7}(E C) \\
+\beta_{8}(F P V)+\beta_{9}(H E)+\beta_{10}(C O M P)+\beta_{11}(I N T)+\beta_{12}(A G E)+\beta_{13}(S I Z E) \\
+\beta_{14}(\text { TICK })+\beta_{15}(C T T)+\mu_{i, t}
\end{aligned}
$$

Where, represents the natural log of trading volume as a measure of success, following Black (1986), Brorsen and Fofana (2001) and Hung et al. (2011) that a continuous variable does not discard relevant information. A list of factors as mentioned in the previous section has been incorporated as explanatory variables for contract success.

The results presented in Table 4 point out that spot market volatility has a positive impact on contract success. The result is consistent with the past studies (See Black, 1986; Corkish et al., 1997; Siqueira, da Silva, and Aguiar, 2008; Hung et al., 2011; Till 2014; Webb, 2015), which have stated this as the most crucial condition for the contract to be successful. A volatile spot market results in the commercial need for hedging to reduce the price risk and thus it is more likely that the contract will be successful. A highly vertically integrated value chain has an adverse effect. This result is in contrast to the expectation based on prior studies (Brorsen and Fofana 2001) as more the number of participants greater should be the demand in the futures market. The probable reason for this could be the presence of inbuilt risk mitigating mechanisms at each level of value chain making futures markets less attractive. There is also a possibility that the risk at each level is even less relative to the cost of trading involved and thus there is little incentive for the players to participate in the futures market, exhibiting a negative relation to the successfulness of the contract. Results concerning geographical coverage are contrary to the belief that greater geographic coverage would lead to a higher number of participants in the derivatives market. It is likely that there is a better price discovery mechanism when there are a number of mandis and thus reducing the need for hedging through a futures contract. In the Indian context, a large number of variants in the spot market, poor warehousing, and grading facilities could be the reasons for this outcome. Perhaps, with the vast geographical coverage, there is a wide disparity in the goods produced making it unviable for the commodity to be traded on the exchange. For the continual success of the futures contract, it is crucial that there is considerable volatility in the futures market, attracting a large number of speculators and thus have a positive impact on the likelihood of the contract to be successful. Several studies in the past have also highlighted the vital role of speculators in providing liquidity in the market (Pennings and Leuthold, 2001; Pennings and Meulenberg, 1997). Gray (1966) and Hyeronymus (1977) Thompson et al. (1996) Brorsen and Fofana 2001; Till 2014, Webb 2015). The outcomes of the study underline that the commodities on which CTT is levied have been adversely affected. The imposition of CTT has led to an increase in the transaction costs and as suggested by Sanders and Pennings (1999), Tavares (2008); Webb (2015) such a rise in the trading costs inhibit the potential of the futures contract to be successful. The coefficient of COMP is significantly positive, consistent with the findings of 
Tashjian and Weissman (1995), Corkish et al. (1997), Hung et al. 2011. These studies argue that the presence of contracts which are related works in favour of the success potential of the contract as it gives the opportunity to spread trading. Thus commodities which are traded on multiple Indian exchanges are more likely to succeed in the Indian commodity derivative market. Another takeaway from the analysis is that as the age of the contract increases, the contract is more successful, thus implying frequent banning of the trading in the derivative market has a detrimental effect on the contract success, as also highlighted by Gulati et al. (2017). Contracts on the underlying commodities which are traded globally on different exchanges are less likely to succeed in the Indian market, owing to increased competition faced from the international exchanges regarding lower transaction costs and efficient price discovery and risk hedging mechanism. The tick size has a significant positive effect on the contract success as higher tick size appears to provide greater compensation to the providers of the liquidity in the market and thus results in higher volume. This result is consistent with the studies (See (Harris (1994), Niemeyer \& Sandås (1994); Ahn et al. (1996); Grossman et al. (1997), Goldstein \& Kavajecz (2000), Aitken and Comerton-Forde (2005) which suggest that for contracts where the liquidity is low, decline in the tick size results in a negative impact on the trading volume.

Table 4. Estimated coefficients from panel data estimations, years 2012- 2017.

\begin{tabular}{|l|l|l|}
\hline Factors & Coefficient & P- value \\
\hline SPV & 1.415 & $0.06^{*}$ \\
\hline CMS & -0.012 & 0.595 \\
\hline SMA & -0.189 & 0.467 \\
\hline VI & -0.488 & $0.033^{* *}$ \\
\hline GC & -0.007 & $0.057^{*}$ \\
\hline Homo & 0.097 & 0.232 \\
\hline EC & 1.392 & 0.152 \\
\hline FPV & 0.030 & $0.091^{*}$ \\
\hline HE & 0.286 & 0.582 \\
\hline Comp & 1.737 & $0.016^{* *}$ \\
\hline Int & -1.935 & $0.087^{*}$ \\
\hline Age & 0.001 & $0.005^{* * *}$ \\
\hline Size & 0.000 & 0.661 \\
\hline Tick & 0.032 & $0^{* * *}$ \\
\hline CTT & -0.268 & $0.048^{* *}$ \\
\hline Constant & 0.480 & 0.752 \\
\hline
\end{tabular}

Notes: The coefficient estimates and t-statistics (in parentheses) reported in the table are obtained from Equation 1:

$$
\begin{aligned}
Y_{i, t}=\alpha_{i}+\beta_{1}(S P V)+\beta_{2}(C M S)+\beta_{3}(S M A)+\beta_{5}(\mathrm{VI})+\beta_{5}(G C)+\beta_{6}(H O M O)+\beta_{7}(E C) \\
+\beta_{8}(F P V)+\beta_{9}(H E)+\beta_{10}(C O M P)+\beta_{11}(I N T)+\beta_{12}(A G E)+\beta_{13}(S I Z E) \\
+\beta_{14}(T I C K)+\beta_{15}(C T T)+\mu_{i, t}
\end{aligned}
$$

Where $Y_{i, t}$ represents the measure of contract success (Natural log of trading volume) as the 
dependent variable. Variables capturing for the spot market characteristics are - SPV, spot market volatility; CMS, spot market size; SMA, dummy variable for spot market activeness; VI, level of vertical integration; Homo, degree of homogeneity; GC, degree of geographical coverage; EC, dummy variable for commodity procured at MSP under the essential commodities act; the characteristics for the future market are FPV, futures market volatility; Comp, dummy variable for competition; INT, dummy variable for commodities listed internationally; CTT, dummy variable for CTT imposition; AGE, number of days of contract life; SIZE, contract size; TICK, measures tick size in rupee terms; HE, hedging effectiveness, measured as the coefficient of determination; If the commodity is produced at MSP under the Essential Commodities act, or if the CTT is imposed, or is listed on any other Indian or international exchange, the dummy variable takes a value 1 or 0 otherwise.

The analysis of the findings confirms some of the parameters and measures used by SEBI in its criteria and suggest a few more factors which have a significant impact on contract success.

A comparison between the factors considered in the SEBI criteria with the set of factors analyzed in the model in the present study offers vital insights. Spot market size and degree of homogeneity, considered under the commodity fundamentals by SEBI don't empirically have a significant impact on the contract success, questioning the emphasis attached with the commodity fundamentals. The study does not include the durability/ storability aspect of the commodity as all the commodities considered under the analysis do not differ much in this aspect. Looking at the trade factors, the findings of the study are in contrast to SEBI expectations about commodities with internationally linked prices being more successful (measured as international listing).

However, commodities with a long value chain and broad geographical coverage (reflected by the number of mandis) do not necessarily lead to the contract being successful, as postulated by SEBI. On the contrary, they might inhibit the contract success, owing to insignificant price risk at each level or inbuilt risk mitigating mechanism present in the spot market. SEBI considers MSP in its criteria but ignores the impact of CTT on contract success. The effect of CTT imposition has been included in our analysis and the results highlight a significant adverse influence. The outcome of the study is in line with SEBI's assumption that higher spot market volatility enhances the contract success potential.

Furthermore, it is recommended that SEBI could look into additional factors under the risk management parameter highlighted by the results like the complementarities existing with the presence of a related contract on multiple exchanges. It may also be relevant for SEBI to include the level of potential volatility in the futures market as a factor when evaluating the commodities to be traded in the Indian agri derivative market as it shows a positive relationship with the contract success. The contract design specifications - lot size, tick size, etc. are ignored in the SEBI's criteria. The results indicate that tick size is a significant factor influencing contract success. SEBI could also strengthen its standards by including the age of the contract when examining the commodities where futures trading should continue to take place, as older the contract, higher the likelihood of success.

In sum, our empirical study highlights that success of the contract is significantly positively 
related to volatility in the spot and future market, existence of duplicate contracts on Indian exchanges, tick size and the age of the contract and considerably negatively associated with level of vertical integration and geographical coverage, CTT imposition and international listing of commodities.

\section{Summary, and conclusion; Policy implications}

Issues related to the Indian agricultural sector have been deliberated extensively, in the academic and political spheres. The role of the agri commodity derivative market has been questioned continuously and often blamed for increased volatility and speculation in the agri commodity, especially in the context of the farmer's distress. This has led to excessive policy interventions and adverse public opinion for the agri commodity derivative market.

Inadequate understanding of the dynamics and structure of the Indian agri market has hampered its growth and development irrespective of the boost given by the government in 2003 by permitting national level exchanges to set up derivatives trading and expanding the list of agri commodities which can be traded. It has been well established that for the agriculture sector to develop, the institutional and regulatory framework for the spot and derivative market needs to be strengthened. In the light of the grave economic consequences of the failure of the contract, the emphasis has been given on the factors which contribute to making the contracts successful, ensuring enough market participation, and generating liquidity in the market. Given the Indian context, it is pertinent to identify, understand and evaluate the determinants which make the agri futures contracts successful.

In the existent study, an effort has been made to empirically analyze the factors influencing the contract prospects of being successful and create an objective, data-driven framework to evaluate their significance. It is relevant for the exchanges, regulators, and policymakers to take appropriate steps in complementarity to develop the agri futures market and ensuring the benefits of the commodity derivative are translated to the real economy regarding better price risk management, price discovery and information transmission. Specifically, the results of the study would facilitate to identify commodities which when introduced would be more likely to succeed.

The review of prior work helps to identify a wide array of characteristics related to the spot and future market which influence the success potential of the commodity in the future contract trading. These factors are examined for 22 commodities from July 2012- July 2017.

The empirical analysis reveals several interesting findings. One of the necessary factors to be considered for ensuring contract success is the presence of spot market volatility. A long value chain and high geographical coverage for a product may limit the futures contract success. Need for commodity market infrastructure, including the availability of warehousing, transport and grading facilities is warranted. The continued success of the contract depends on the futures price volatility, which should be substantial enough to attract speculators in the market. The findings of the study point toward that frequent bans/suspensions hurt the market sentiment, create a lot of uncertainty and thus hamper the success prospects of the contract. A long-lived contract has greater success potential than the newly launched contract. 
Additionally, the imposition of CTT has increased the trading costs, making it expensive to trade and causing a shift of the trading volumes to the international platforms wherever possible. This is validated by a negative impact of international listing on the likelihood of contract success. It is vital for the policymakers to encourage the market participants by providing incentives to trade in the Indian agri derivative market. Tick size, a contract design specification, has a positive and significant coefficient. The Indian agri derivative market suffers from low liquidity, and higher tick size provides greater compensation to the providers of the liquidity in the market, which is crucial for the market to develop. The coefficient of COMP is significantly positive, indicating that in the Indian context, probably trading in a set of related contracts is more profitable and thus the presence of contracts (with same underlying commodities) on different exchanges results in higher trading volumes.

The study outcomes are relevant for all the stakeholders in the Indian agri commodity derivative market as it augments the understanding of factors having an impact on the success potential of the contract. The findings suggest that resources should not be wasted in permitting commodities, where there is negligible volatility in the spot market. Efforts should be directed towards creating a conducive environment for the contract to be successful instead of suspending contracts frequently. A system of commodity surveillance both at the level of exchange and regulator should be put in place for regular reviewing and monitoring of the significant factors. A continuous reassessment of the changing fundamentals of the commodities would enable them to take corrective measures well in time. It is also vital for the government to reconsider the levy of CTT on the agro-processed goods in light of the detrimental impact it has on the success potential of the contract.

It is essential for the exchange that the contract is effectively designed in a manner to attract both hedgers and speculators. Individually, the impact of tick size on the liquidity should be evaluated before making any modifications. Additionally, exchanges should take active steps for investor education to encourage higher participation in the agri commodity derivative market. Proactive measures should be taken to develop the derivatives market for spices, where India dominates the global market and is the only platform for derivative trading.

The study provides an empirical basis to the criteria adopted by SEBI and attempts to quantify the variables considered, which would help in undertaking necessary reform, giving clarity for permitting and retaining commodities to trade, ensuring more involvement in futures trading (hedgers and speculators), strengthening the regulatory policy framework with minimal interventions in future.

In India, as of now, only a few commodities are traded in the agri derivative market. Further research should assess the viability of remaining commodities (especially which are permitted) for potentially being traded on the Indian exchanges. It will also be of interest to evaluate the relevant which determine the success of the agri options contract in the Indian context. The future studies should even attempt to analyze the perceptions and opinions of various stakeholders of the Indian agri commodity market to have more profound insights about the issues of Indian agri commodity derivatives market besides relying solely on secondary data.

The present work makes a relevant contribution to the literature of the agri commodity market 
of an emerging economy, India.

\section{Acknowledgement}

We thank the anonymous referees for their valuable suggestions.

\section{References}

Ahn, H. J., Cao, C. Q., \& Choe, H. (1996). Tick size, spread, and volume. Journal of Financial Intermediation, 5(1), 2-22. https://doi.org/10.1006/jfin.1996.0002

Aitken, M., \& Comerton-Forde, C. (2005). Do reductions in tick sizes influence liquidity? Accounting \& Finance, 45(2), 171-184. https://doi.org/10.1111/j.1467-629x.2004.00128.x

Ajoy Kumar, M., \& Shollapur, M. R. (2015). Price Discovery and Volatility Spillover in the Agricultural Commodity Futures Market in India. IUP Journal of Applied Finance, 21(1).

Baer, J.B., Saxon, O.G. (1949). Commodity Exchanges and Futures Trading. Harper Brothers, New York

Bekkerman, A., \& Tejeda, H. A. (2017). Revisiting the determinants of futures contracts success: the role of market participants. Agricultural economics, 48(2), 175-185. https://doi.org/10.1111/agec.12324

Bhardwaj, G., Gorton, G., \& Rouwenhorst, G. (2015). Facts and fantasies about commodity futures ten years later (No. w21243). National Bureau of Economic Research. https://doi.org/10.3386/w21243

Bialkowski, J., \& Jakubowski, J. (2012). Determinants of Trading Activity on theSingle-Stock Futures Market: Evidence from the Eurex Exchange. The Journal of Derivatives, 19(3), 29-47. https://doi.org/10.3905/jod.2012.19.3.029

Białkowski, J., \& Koeman, J. (2018). Does the design of spot markets matter for the success of futures markets? Evidence from dairy futures. Journal of Futures Markets, 38(3), 373-389. https://doi.org/10.1002/fut.21883

Black, D. G. (1986). Success and failure of futures contracts: theory and empirical evidence. Salomon Brothers Center for the Study of Financial Institutions, Graduate School of Business Administration, New York University.

Bollen N, Smith T, Whaley R (2003). Optimal Contract Design: For Whom? J. Futures Markets, 23, 719-750. https://doi.org/10.1002/fut.10086

Bollman, K., Garcia, P., \& Thompson, S. (2003). What killed the diammonium phosphate futures contract?. Review of Agricultural Economics, 25(2), 483-505. https://doi.org/10.1111/1467-9353.00151

Brorsen, B. W., \& Fofana, N. Z. F. (2001). Success and failure of agricultural futures contracts. Journal of Agribusiness, 19(345-2016-15191), 129. 10.22004/ag.econ.14692 
Brown, Sh., Laux, P. and Schachter, B. 1991. On the Existence of an Optimal Tick Size. Rev. Futures Markets, 10, 50-72.

Carlton, D. W. (1984). Futures markets: Their purpose, their history, their growth, their successes and failures. Journal of Futures Markets, 4(3), 237-271. https://doi.org/10.1002/fut.3990040302

Chordia, T., \& Subrahmanyam, A. (1995). Market making, the tick size, and payment-for-order flow: theory and evidence. Journal of Business, 543-575. https://doi.org/10.1086/296676

Corkish, Jo and Holland, Allison M. and Vila Wetherilt, Anne, The Determinants of Successful Financial Innovation: An Empirical Analysis of Futures Innovation on Liffe (October 1997). Bank of England Working Paper No. 70. http://dx.doi.org/10.2139/ssrn.115068

Cornell, B. (1981). The relationship between volume and price variability in futures markets. Journal of Futures Markets, 1(3), 303-316. https://doi.org/10.1002/fut.3990010303

Dew, J. K. (1981). Comments on "innovation, competition, and new contract design in futures markets". Journal of Futures Markets, 1(2), 161-167. https://doi.org/10.1002/fut.3990010207

Du, Wen, 2004. "International Market Integration Under Wto: Evidence In The Price Behaviors Of Chinese And Us Wheat Futures," 2004 Annual meeting, August 1-4, Denver, CO 20115, American Agricultural Economics Association (New Name 2008: Agricultural and Applied Economics Association).

Ederington, L. H. (1979). The hedging performance of the new futures markets. The Journal of Finance, 34(1), 157-170. https://doi.org/10.1111/j.1540-6261.1979.tb02077.x

Frino, A. (1997). Is there an optimum tick size in futures markets. Securities Industry Research Centre of Asia-Pacific (SIRCA).

Garcia, P., Irwin, S. H., \& Smith, A. (2015). Futures market failure? American Journal of Agricultural Economics, 97(1), 40-64. https://doi.org/10.1093/ajae/aau067

Goldstein, M. A., \& Kavajecz, K. A. (2000). Eighths, sixteenths, and market depth: changes in tick size and liquidity provision on the NYSE. Journal of Financial Economics, 56(1), 125 149. https://doi.org/10.1016/S0304-405X(99)00061-6

Gorham, M., \& Kundu, P. (2012). A half-century of product innovation and competition at US futures exchanges. REVIEW OF FUTURES, 105.

Gray RW (1966). Why does futures trading succeed or fail: an analysis of selected commodities? In Futures Trading Seminar, 3, 115-137.

Grossman, Sanford, Merton Miller, Kenneth Cone, Daniel Fischel and David Ross, 1997, Clustering and competition in asset markets. Journal of Law and Economics, 40, 23-60. https://doi.org/10.1086/467365 
Gulati, A., Chatterjee, T., \& Hussain, S. (2017). Agricultural Commodity Futures: Searching for Potential Winners (pp. 1-21, Working paper No. 349). New Delhi, Delhi: ICRIER. https://icrier.org/pdf/Working_Paper_349.pdf

Gupta, C. P., Sehgal, S., \& Wadhwa, S. (2018). Agricultural Commodity Trading: Is it Destabilizing Spot Markets?. Vikalpa, 43(1), 47-57. https://doi.org/10.1177/0256090917750263

Harris, L. (1998). Optimal dynamic order submission strategies in some stylized trading problems. Financial Markets, Institutions \& Instruments, 7(2), 1-76. https://doi.org/10.1111/1468-0416.00019

Harris, L. (1994). Minimum Price Variations, Discrete Bid-Ask Spreads, and Quotation Sizes. Review of Financial Studies, 7, 149-178. https://doi.org/10.1093/rfs/7.1.149

Hieronymus, T. A. (1977). Economics of futures trading for commercial and personal profit (pp. 71-94). New York, NY: Commodity Research Bureau.

Holder, M., Tomas, M., \& Webb, R. (1999). Winners and Losers: Recent Competition Among Futures Exchanges for Equivalent Financial Contracts. Derivatives Quarterly, 6(2), 19.

Hosseini-Yekani, S. A., Zibaei, M., \& Allen, D. E. (2009). The choice of feasible commodities for futures trading: a study of Iranian agricultural commodities. African Journal of Agricultural Research, 4(3), 193-199.

Hull, J (2000). Options, Futures, and other Derivatives. Prentice Hall, New York.

Hung, M. W., Lin, B. H., Huang, Y. C., \& Chou, J. H. (2011). Determinants of futures contract success: Empirical examinations for the Asian futures markets. International Review of Economics \& Finance, 20(3), 452-458. https://doi.org/10.1016/j.iref.2010.11.015

Iyer, V., \& Pillai, A. (2010). Price discovery and convergence in the Indian commodities market. Indian Growth and Development Review, 3(1), 53-61. https://doi.org/10.1108/17538251011035873

Kapur, R., Chouhan, S., Kumar, D., Sarin, R., \& Rajput, N. (2018, April). India - Pushing the right levers (Publication). Retrieved August 12, 2018, from IBEF website: https://www.ibef.org/download/IBEF-Theme-1-15-updated-low.pdf

Karagozoglu, A. K., \& Martell, T. F. (1999). Changing the size of a futures contract: Liquidity and microstructure effects. Financial Review, 34(4), 75-94. https://doi.org/10.1111/j.15406288.1999.tb00470.x

Kolb, R. W. (1991). Understanding Futures Markets, 3rd edition. Miami, FL: Kolb

Kumar, M., Agrawal, T. J., \& Sehgal, S. (2017). Domestic and International Information Linkages for Indian Commodities Market in the Pre-and Post-CTT Periods. Metamorphosis, 16(2), 75-91. https://doi.org/10.1177/0972622517737869 
Kurov, A. (2008). Tick size reduction, execution costs, and informational efficiency in the regular and E-mini Nasdaq-100 index futures markets. Journal of Futures Markets: Futures, Options, and Other Derivative Products, 28(9), 871-888. https://doi.org/10.1002/fut.20341

Kurov, A., \& Zabotina, T. (2005). Is it time to reduce the minimum tick sizes of the E-mini futures?. Journal of Futures Markets: Futures, Options, and Other Derivative Products, 25(1), 79-104. https://doi.org/10.1002/fut.20119

Longin, F. M. (1999). Optimal margin level in futures markets: Extreme price movements. Journal of Futures Markets: Futures, Options, and Other Derivative Products, 19(2), 127-152. https://doi.org/10.1002/(SICI)1096-9934(199904)19:2<127::AID-FUT1>3.0.CO;2-M

Meulenberg, M. T., \& Pennings, J. M. (2002). A marketing approach to commodity futures exchanges: A case study of the Dutch hog industry. Journal of Agricultural Economics, 53(1), 51-64. https://doi.org/10.1111/j.1477-9552.2002.tb00005.x

Ministry of Finance, Government of India. (2015). Retrieved February 12, 2018 from https://www.indiabudget.gov.in/budget2015-2016/survey.asp

Ministry of Finance, Government of India. (2018). Economic Survey 2017-18, OUP Catalogue, Oxford University Press, ISBN 9780199489398.

Nath, G. C., \& Lingareddy, T. (2008). Impact of futures trading on commodity prices. Economic and Political Weekly, 18-23.

Niemeyer, J., \& Sandas, P. (1994). An empirical analysis of the trading structure at the Stockholm Stock Exchange. Journal of Multinational Finance Management, 3(3-4), 63-101.

Pennings JME, Egelkraut TM (2003). Research in Agricultural Futures Markets: Integrating the Finance and Marketing Approach. Agrarwirtschaft, 52, 300-308.

Pennings, J. M., \& Garcia, P. (2001). Measuring producers' risk preferences: a global riskattitude construct. American Journal of Agricultural Economics, 83(4), 993-1009. https://doi.org/10.1111/0002-9092.00225

Pennings, J. M., \& Leuthold, R. M. (2001). Introducing new futures contracts: reinforcement versus cannibalism. Journal of International Money and Finance, 20(5), 659-675. https://doi.org/10.1016/S0261-5606(01)00013-4

Pennings, J. M., \& Meulenberg, M. T. (1997). The hedging performance in new agricultural futures markets: a note. Agribusiness: An International Journal, 13(3), 295-300. https://doi.org/10.1002/(SICI)1520-6297(199705/06)13:3<295::AID-AGR4>3.0.CO;2-W

Powers, M. J. (1967). Effects of contract provisions on the success of a futures contract. Journal of Farm Economics, 49(4), 833-843. https://doi.org/10.2307/1236940

Pravakar Sahoo \& Rajiv Kumar, 2008. "Impact Of Proposed Commodity Transaction Tax On Futures Trading In India," Finance Working Papers 22239, East Asian Bureau of Economic Research. 


\section{$\Lambda$ Macrothink}

Asian Journal of Finance \& Accounting

ISSN 1946-052X 2019, Vol. 11, No. 2

Purcell, W. D., \& Koontz, S. R. (2003). Agricultural Futures and Options, Principles and Strategies. Second Editions, Prentice Hall, New York.

Quintino, D. D., \& David, S. A. (2013). Quantitative analysis of the feasibility of hydrous ethanol futures contracts in Brazil. Energy Economics, 40, 927-935. https://doi.org/10.1016/j.eneco.2013.07.027

Ray, S., \& Malik, N. (2014). Impact of transaction taxes on commodity derivatives trading in India (No. 272). Working Paper.

Roche, J. (2016). Hot or not: chances of success for the launch of the red chilli futures contract by the Pakistan mercantile exchange. Journal of Agricultural Policy \& Food Security, 1(1), 111.

Sahi, Gurpreet S., \& Raizada, Gaurav. Commodity Futures Market Efficiency in India and Effect on Inflation. http://dx.doi.org/10.2139/ssrn.949161

Sahoo, P., \& Kumar, R. (2011). The impact of commodity transaction tax on futures trading in India: An ex-ante analysis. The Singapore Economic Review, 56(03), 423-440. https://doi.org/10.1142/S0217590811004328

Sahoo, Pravakar, \& Kumar, Rajiv. (2008). Impact Of Proposed Commodity Transaction Tax On Futures Trading In India, Working Paper, No. 216, Indian Council for Research on International Economic Relations (ICRIER), New Delhi

Sanders, D. R., \& Pennings, J. M. (1999). They Trade Shrimp in Minneapolis? An Examination of the MGE White Shrimp Futures Contract. In Presented paper at NCR-134 Conference on Applied Commodity Price Analysis, Forecasting, and Market Risk Management, ed. TC Schroeder (pp. 273-88).

Sandor, R. L. (1973). Innovation by an exchange: A case study of the development of the plywood futures contract. The Journal of Law and Economics, 16(1), 119-136. https://doi.org/10.1086/466758

Securities and Exchange Board of India. (2016). 2016 annual report of the Securities and Exchange Board of India. Retrieved from https://www.sebi.gov.in/reports/annual-reports/aug2016/annual-report-2015-16_33014.html

Sehgal, S., \& Agrawal, T. J. (2019). Impact of Commodity Transaction Tax on Market Liquidity, Volatility, and Government Revenues: An Empirical Study for India. Vikalpa, 0256090919826316. https://doi.org/10.1177/0256090919826316

Sehgal, Sanjay and Ahmad, Wasim,(2013) On the Possible Impact of Commodity Transaction Tax on India's Commodity Derivatives: An Empirical Study (March 27, 2013). http://dx.doi.org/10.2139/ssrn.2417095

Seth, N., \& Sidhu, A. (2018). Price Discovery and Volatility Spillovers in Indian Wheat Market: An Empirical Analysis. IUP Journal of Applied Finance, 24(2), 5-20. 
Shihabudheen, M. T., \& Padhi, P. (2010). Price discovery and volatility spillover effect in Indian commodity market. Indian Journal of Agricultural Economics, 65(1), 101-117.

Silber, W. L. (1981). Innovation, competition, and new contract design in futures markets. Journal of Futures Markets, 1(2), 123-155. https://doi.org/10.1002/fut.3990010205

Siqueira, K. B., da Silva, C. A. B., \& Aguiar, D. R. (2008). Viability of introducing milk futures contracts in Brazil: a multiple criteria decision analysis. Agribusiness, 24(4), 491-509. https://doi.org/10.1002/agr.20175

Sittisawad, T., \& Sukcharoensin, P. (2018). Success Factors of Financial Derivatives Markets in Asia. Asia-Pacific Financial Markets, 25(2), 71-86. https://doi.org/10.1007/s10690-0189239-4

Tashjian, E. (1995). Optimal futures contract design. The Quarterly Review of Economics and Finance, 35(2), 153-162. https://doi.org/10.1016/1062-9769(95)90012-8

Tashjian, E., \& Weissman, M. (1995). Advantages to competing with yourself: why an exchange might design futures contracts with correlated payoffs. Journal of Financial Intermediation, 4(2), 133-157. https://doi.org/10.1006/jfin.1995.1007

Tavares, M. F. D. F. (2008). Future and physical market of FCOJ: knowledge and use by citrus agribusiness of brazil. Revista Brasileira de Fruticultura, 30(4), 925-930. https://doi.org/10.1590/S0100-29452008000400015

Thomas, S. (2003, May 21). Agricultural commodity markets in India: Policy issues for growth (Tech.). Retrieved April 23, 2017, from Indira Gandhi Institute for Development Research website:

http://citeseerx.ist.psu.edu/viewdoc/download?doi=10.1.1.197.6692\&rep=rep1\&type=pdf

Thomas, S., \& Karande, K. (2001). Price discovery across multiple spot and futures markets. IGIDR, Mumbai, http//www. igidr. ac. in , 23.

Thompson, S., \& Kunda, E. (2000). The role of organized exchanges and standardized contracts in marketing new commodities. In Producer Marketing and Risk Management: Frontiers for the 21st Century. Conference Proceedings Orlando, Florida, USA, 13-14 January 2000. (pp. 1-36). Department of Agriculture and Applied Economics, University of Minnesota.

Thompson, S., Garcia, P., \& Wildman, L. D. (1996). The demise of the high fructose corn syrup futures contract: a case study. Journal of Futures Markets: Futures, Options, and Other Derivative Products, 16(6), 697-724. https://doi.org/10.1002/(SICI)10969934(199609)16:6<697::AID-FUT5>3.0.CO;2-A

Till, Hilary, Why Some Commodity (and Financial) Futures Contracts Succeed and Others Fail: A Survey of Relevant Research (October 1, 2014). Forthcoming in the Journal of Alternative Investments. http://dx.doi.org/10.2139/ssrn.2573894 


\section{Macrothink}

UNCTAD, 2019, Managing commodity price risk in commodity-dependent developing countries, Report by the UNCTAD secretariat. New York: United Nations. Retrieved January 12, 2019 from https://unctad.org/meetings/en/SessionalDocuments/cimem2d46_en.pdf

Wasim Ahmad, Sanjay Sehgal. (2015). The investigation of destabilization effect in India's agriculture commodity futures market: An alternative viewpoint. Journal of Financial Economic Policy, 7(2), 122-139, https://doi.org/10.1108/JFEP-02-2014-0008

Webb, R. (2015). What drives success in futures markets. Keynote speech, 2015 Derivative Markets Conference.

Williams, J., Peck, A., Park, A., \& Rozelle, S. (1998). The emergence of a futures market: Mungbeans on the China Zhengzhou Commodity Exchange. Journal of Futures Markets: Futures, Options, and Other Derivative Products, 18(4), 427-448.

\section{Copyright Disclaimer}

Copyright for this article is retained by the author(s), with first publication rights granted to the journal.

This is an open-access article distributed under the terms and conditions of the Creative Commons Attribution license (http://creativecommons.org/licenses/by/3.0/). 